\title{
Musk deer Moschus moschiferus nutrition in the Tukuringra Mountain Range, Russian Far East, during the snow season
}

\author{
Trofim A. Domanov
}

\begin{abstract}
The study of musk deer nutrition was conducted during the 2010-2013 snow seasons on the Tukuringra Mountain Range, Russian Far East. Gastric content analysis and detailed tracking was conducted as well. Sixty four kinds of forage preferred by musk deer were recorded. Data on forage composition in different habitats were received. Peculiarities of the musk deer nutrition on the Tukuringra Mountain Range were revealed.
\end{abstract}

KEY WORDS: nutrition, musk deer, lichens, shrub, Tukuringra Mountain Range, forage.

Trofim A. Domanov [domanov.t@yandex.ru], Federal State Budgetary Institution “Zeya State Nature Reserve”, Stroitelnaya str. 71, Zeya 676243, Russia.

\section{Питание кабарги Moschus moschiferus на хребте Тукурингра, Дальний Восток, в снежный период года}

\begin{abstract}
Т.А. Доманов
РЕЗЮМЕ: В период 2010-2013 гг. на хребте Тукурингра (Дальний Восток России) были проведены исследования питания кабарги в снежный период. Осуществлен анализ содержимого желудков и ряд детальных троплений. Зафиксировано 64 вида корма, предпочитаемые кабаргой. Получены данные о составе кормов в различных местообитаниях. Выделены особенности питания кабарги на хребте Тукурингра.
\end{abstract}

КЛЮЧЕВЫЕ СЛОВА: питание, кабарга, лишайники, кустарники, хребет Тукурингра, вид корма.

\section{Introduction}

Musk deer (İoschus moschiferus Linnaeus, 1758) is a representative of small ungulates. These animals live in mountain taiga ecosystems of Asia. For a long time ecologists knew that nutrition of animals and their food chains depend mainly on biocenoses. There is hardly any ecological report not touching upon these important issues (Novikov, 2009). Currently there are data on forage composition of musk deer from the Eastern Sayan Mountains, Transbaikalia, Sakha Republic, and Russian Far East (Ustinov, 1969; Prikhod'ko, 2003; Zaitsev, 2006; Krivoshapkin, 2008).

On the Tukuringra Mountain Range (Russian Far East) a musk deer is considered to be common species. Musk deer inhabit different areas of the mountain range because this area is situated on the border the units of phytogeographical zoning (Gubanov, 1981). Therefore, forage stations of this species can consist of different eatable items. Currently nutrition of musk deer during snow seasons has not been completely studied (Domanov, 2012a). Therefore, it is important to study this aspect of the species ecology.

\section{Material and methods}

Material has been collected during the period of 2010-2012 on Tukuringra Mountain Range, which is located in Amur region (Russian Far East) and is a part of the Tukuringra and Dzhagdy Ecoregion. The main relief categories of the Eastern part of the mountain range are sharply dissected mid-mountains and slightly dissected low mountains (Gubanov, 1981). The relief of the Eastern part of this mountain range is represented by slightly dissected mid-mountains. The altitudes vary from 500 to $1604 \mathrm{~m}$ above sea level. The rivers of the territory under discussion belong to Amur and Zeya basins. There are spruce and Chosenia forests, larch forests with some poplars (Populus maximowiczii) there kinds of alder trees (Alnus fruticosa, A. hirsuta, A. sibirica) and red dogwood trees (Swida alba) in the undergrowth, depauperated larch forests (Larix gmelini) with reindeer moss and dwarf birch trees (Betula middendorffii) grow in the river valleys. Larch is frequent on the slopes, while spruce (Picea ajanensis) and birch trees (Betula platyphylla) are less frequent. Open larch forests and mountain pine (Pinus pumila) are widely spread in the watershed. Large areas of open reindeer moss and larch forests grow on the gentle slopes of the central and Western parts of the mountain range, along with mountain pines and dwarf birch trees as an undergrowth. These areas are inhabited by musk deer, even though the conditions are not very favorable for them here (Domanov, 2012b).

Methods applied by various authors in different regions were used in the process of studying nutrition: 


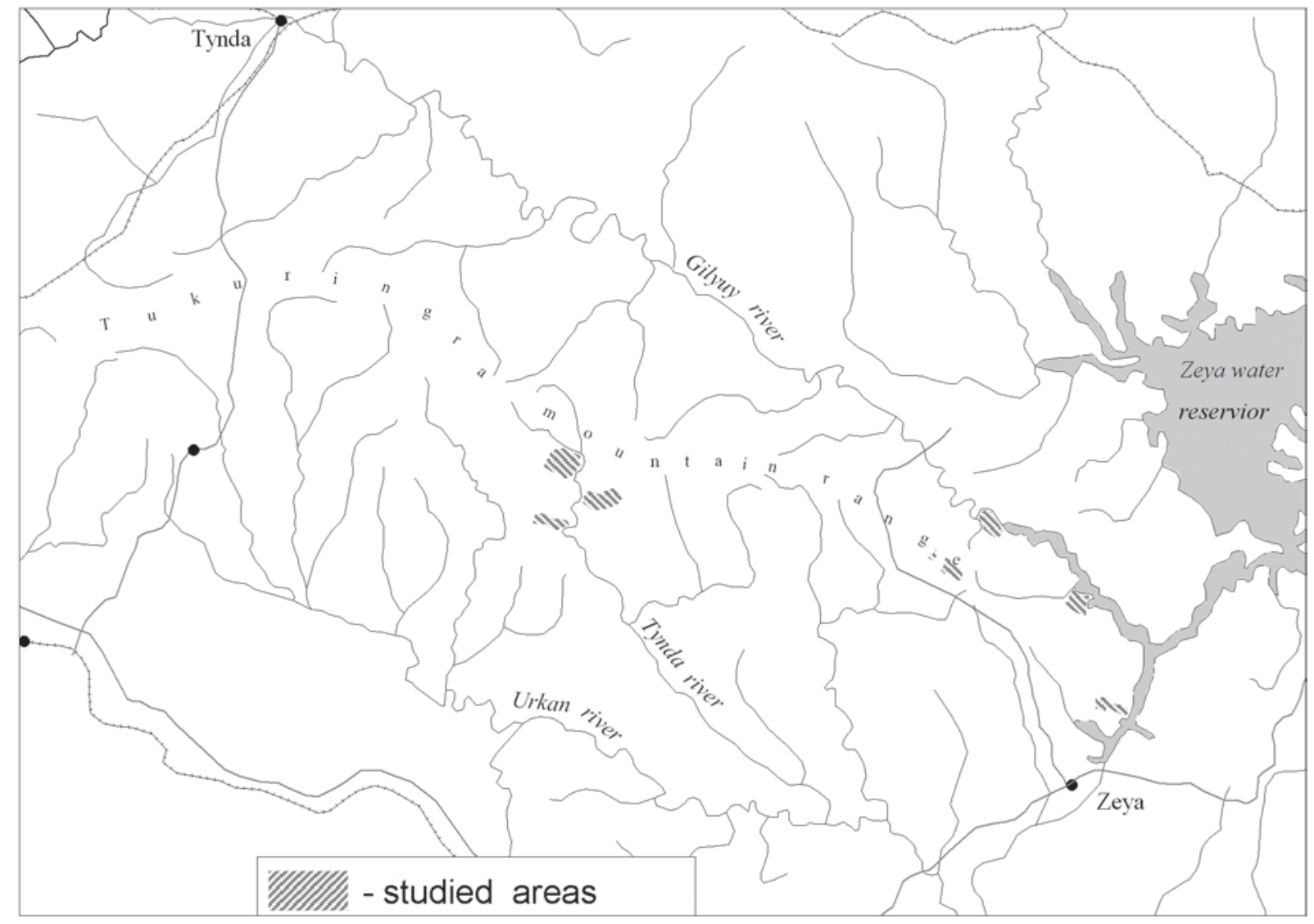

Figure. The areas chosen to be studied for musk deer nutrition using the method of tracking.

forage stations were inspected, tracked in details (daily and partially), grazers were observed, and gastric contents was analysed (Bannikov et al., 1978; Argunov, 2009; Mirutenko et al., 2009; Maslov, 2011). These methods were practiced in the eastern part of the Tukuringra Mountain Range (headstream of the Tynda River) on the hunting territories, and also in the eastern part of the same mountain range on the territory of the Zeya Nature Reserve.

Musk deer forage stations were investigated, animal behavior was observed, and forage trails were studied, taking into account plant, fungus, and lichen species.

Tracking was performed on the southern and northern macroslopes of the Tukuringra Mountain Range (Fig. 1). There were 26 full days and 18 partial days of tracking, including two multiple day tracking. Total tracking distance was $43.4 \mathrm{~km}$. The distance of tracking was measured with the GPS and counted by the steps (Mirutenko et al., 2009). We registered types of forage. In total 2444 food remains debris were recorded. The specific weight of forage items was calculated, as well as their frequency. According to the daily tracking data, the number of different kinds of plants eaten by the animals was determined for each day. All unknown plants were collected for the further identification.

The average snow depth was $0.19-1 \mathrm{~m}$ on the tracking areas during the whole period of study. Most types of musk deer habitats of the Tukuringra Mountain Range were studied (Tab. 1).

The content of rumen (the first and the biggest part of four-chambered stomachs in ruminant artiodactyls) was also analyzing. It is helpful in evaluating of the weighting of different food items in the feed ration of a ruminant animal in a particular period (Prikhod'ko, 2003; Abaturov, 2005).

Other authors used this method to study musk deer nutrition in different parts of their natural habitat (Ustinov, 1969; Bannikov et al., 1978; Zheng \& Pi, 1979; Prikhod'ko, 1992; Liu \& Sheng, 2000). We studied 16 musk deer stomachs during the 2012-2013 winter period on the hunting territories of the Tyndinskiy Promkhoz and the Amuroblpotrebsoyuz. A few stomachs were received from local hunters $(n=10)$, while others were found in dead musk deer specimens killed by predators $(n=6)$. Then is used sampling methodology of the stomach (Argunov, 2009; Mosolov \& Fil, 2010). One sample of $250 \mathrm{ml}$ is taken from each of the stomach.

The samples were weighed on the electronic scales with a precision of $0.01 \mathrm{~g}$. Specific weight of the samples was measured as well. All samples were taken as $100 \%$. Some fragments of lichens, shrubs, subshrubs, fungi, and woody plants were singled out during the analysis. The frequency of different forage types occurrence has also been determined (Tabs. 2, 3). Poorly 
Table 1. Musk deer tracking in the Tukuringra Mountain Range.

\begin{tabular}{|l|c|c|c|c|}
\hline \multirow{2}{*}{ Type of habitat (river basin) } & \multicolumn{3}{|c|}{ Number of trackings } & \multirow{2}{*}{ Total, km } \\
\cline { 2 - 4 } & Partial & One day & Multiple days & \multirow{2}{*}{4.1} \\
\hline Open larch forest (Gilyuy River, Shatamu River) & 3 & 2 & 0 & 5.8 \\
\hline $\begin{array}{l}\text { Dense ripe larch forest with spruces on the second layer } \\
\text { (Kamenistaya River, Bolshaya Erakingra River) }\end{array}$ & 3 & 1 & 0 & 22.5 \\
\hline $\begin{array}{l}\text { Dense ripe larch forest with birch trees and } \\
\text { hododendrons (Gilyui River, Motovaya River, Sivak } \\
\text { River) }\end{array}$ & 5 & 12 & 1 (4 days) & 3.9 \\
\hline $\begin{array}{l}\text { Black birch tree forest with Mongolian oaks and aspens } \\
\text { (Razvedochnaya River, Sukhaya River) }\end{array}$ & 3 & 2 & 0 & 2.6 \\
\hline $\begin{array}{l}\text { Sub-barrens Yezo spruce forest (headstream of Shatamu } \\
\text { River, headstreams of Bannaya and Kamenushka River) }\end{array}$ & 1 & 2 & 0 & 4.5 \\
\hline $\begin{array}{l}\text { Burnt wood 3-10 years old (Baranovskaya River, } \\
\text { Razvedochnaya River, Bolshaya Tynda River) }\end{array}$ & 3 & 7 & 1 (5 days) & 2 \\
\hline Total trackings & 18 & 26 & 2 & 43.4 \\
\hline
\end{tabular}

Table 2. Frequency of forage occurrence during snow seasons in the Tukuringra Mountain Range according to the rumen analysis data.

\begin{tabular}{|c|c|c|c|}
\hline Type of forage & & $\begin{array}{l}\text { Frequency of } \\
\text { occurrence, \% }\end{array}$ & $\begin{array}{l}\text { Specific weight, } \\
\% \text { (limits) }\end{array}$ \\
\hline \multirow{4}{*}{ Lichen } & Usnea $\mathrm{sp}$. & 31.25 & $5.23(2.00-33.70)$ \\
\hline & Evernia sp. & 68.75 & $24.92(1.00-85.50)$ \\
\hline & Bryoria sp. & 25.00 & $2.23(2.20-23.25)$ \\
\hline & Cladonia $\mathrm{sp}$. & 56.25 & $22.81(5.10-82.10)$ \\
\hline \multirow{4}{*}{ Herbaceous } & Small reed & 18.75 & \multirow{4}{*}{$1.60(0.20-24.00)$} \\
\hline & Carex sp. & 43.75 & \\
\hline & Doelingeria scabra & 6.25 & \\
\hline & Fern & 12.50 & \\
\hline \multirow{5}{*}{ Shrubs and subshrubs } & Bushy alder tree & 50.00 & \multirow{5}{*}{$18.28(0.40-45.50)$} \\
\hline & Middendorff birch tree & 12.50 & \\
\hline & Dahurian rhododendron & 18.75 & \\
\hline & Prickly wild rose & 6.25 & \\
\hline & Red bilberry & 31.25 & \\
\hline \multirow{5}{*}{ Arboreal } & Dahurian larch buds & 6.25 & \multirow{5}{*}{$21.74(1.00-48.52)$} \\
\hline & Dahurian larch needles & 68.75 & \\
\hline & Ayan spruce needles & 12.50 & \\
\hline & Willow leaves & 31.25 & \\
\hline & $\begin{array}{l}\text { Wood, tree branches, Japanese white } \\
\text { birch leaves }\end{array}$ & 56.25 & \\
\hline \multirow{2}{*}{ Mosses } & Frondiferous & 12.50 & \multirow{2}{*}{$1.72(0.10-2.73)$} \\
\hline & Sphagnum & 25.00 & \\
\hline Fungi & Arboreous & 12.50 & $1.20(3.50-15.64)$ \\
\hline \multirow{2}{*}{ Small mammals } & Laxmann's shrew & 6.25 & \multirow{2}{*}{$0.27(0.10-2.00)$} \\
\hline & Grey red-backed vole & 25.00 & \\
\hline
\end{tabular}

chopped forage fragments, such as leave and stem parts, lichen frond parts, seeds helped to identify the kinds of plants.

\section{Results and discussion}

In total 192 species of vascular plants, fungi, lichens were found in the diet of Siberian musk deer.
They belong to 55 families (Prikhod'ko, 1992). The composition of forage strongly depends on the natural habitat of musk deer (Khumes, 2004). Thus, they eat more than 34 species in the Sakha Republic (Egorov, 1965). Forty nine species of plants consumed by musk deer were found in Altai region (Shaposhnikov, 1965). More than 19 species were found in Primorye region (Salmin, 1972). 
Table 3. Frequency of occurrence and correlation of different forage types in musk deer nutrition, according to tracking results in the Tukuringra Mountain Range.

\begin{tabular}{|l|l|c|c|}
\hline \multicolumn{2}{|l|}{ Type of forage } & Frequency of occurrence, \% & Correlation, \% (limits) \\
\hline \multirow{2}{*}{ Fungi } & Arboreal & 29.41 & $1.16(0.39-3.39)$ \\
\cline { 2 - 4 } & Pileate & 17.64 & $1.02(0.30-2.17)$ \\
\hline \multirow{2}{*}{ Lichens } & Arboreal & 94.10 & $28.23(2.29-53.68)$ \\
\cline { 2 - 4 } & Terrestrial & 35.29 & $15.92(16.64-46.76)$ \\
\hline Mosses & 58.82 & $8.58(0.26-23.15)$ \\
\hline Herbaceous & 58.82 & $0.97(0.37-2.24)$ \\
\hline Shrubs and subshrubs & 94.10 & $34.36(1.30-88.54)$ \\
\hline Arboreal & 70.58 & $3.10(0.96-11.11)$ \\
\hline Small mammals & 2.38 & $0.04(0-0.19)$ \\
\hline
\end{tabular}

On the Tukuringra Mountain Range our study found 64 species of forage items consumed by musk deer during the snow season, including 41 species of vascular plants, 13 species of lichens, four species of fungi, and two species of mammals. In average, the animals consumed 10 species of forage per day. The ration of the animals consisted of a particular number of species in each type of habitat. The greatest variety of forage species was discovered during tracking in black birch forests with oaks on steep slopes and in larch forest with birch trees on gentle slopes, and in the valley. In these kinds of habitat musk deer had 17-18 species of forage per day. The poorest variety of species was discovered in sub-barrens spruce forests with some larches and in ripe larch forests with some spruces. In these areas the animals eat 5-6 species per day. The composition of forage species depended on the depths of snow cover.

\section{List of forage components occur in musk deer diet during snow seasons}

Fungi

Family Polyporaceae

1. Birch polypore (Piptoporus betulinus)

Family Poriaceae

2. Violet-toothed polypore (Trichaptum biforme)

Family Hymenochaetales

Pellinus sp.

3. Family Russulaceae

4. Russula $\mathrm{sp}$.

\section{Lichens}

Family Parmeliaceae

5. Parmotrema chinensis

6. Parmelia saxatilis

7. Hypogymnia enteromorpha

8. Vulpicida pinastri

9. Platismatia glauca

10. Bryoria implexa

11. Cetraria chrysantha

12. Cetraria laevigata
13. Usnea longissima

14. Evernia mesomorpha

Family Cladoniaceae

15. Cladonia coccifera

16. Cladonia rangiferina

17. Cladonia stellaris

Family Stereocaulaceae

18. Stereocaulon alpinum

Bryophytes

Class Bryopsida

19. unknown species

Family Sphagnaceae

20. Sphagnum sp.

Vascular plants

Family Fabaceae

21. Vicia sp.

22. Bicolor lespedeza (Lespedeca bicolor)

Family Asteraceae

23. Saussurea neoserrata

24. Wormwood, 2 species (Artemisia spp.)

25. Doelingeria scabra

26. Narrowleaf hawksbeard (Crepis tectorum)

Family Plantaginaceae

27. Siberian veronicastrum (Veronicastrum sibiricum)

Family Cyperaceae

28. Cotton grass (Eriophorum sp.)

29. Carex sp.

Family Rosaceae

30. Red raspberry (Rubus idaeus)

31. Bird cherry (Prunus padus)

32. False Spiraea (Sorbaria sorbifolia)

33. Prickly wild rose (Rosa acicularis)

34. Ussurian meadowsweet (Spiraea ussuriensis)

Family Oleaceae

35. Amur lilac (Syringa amurensis)

Family Betulaceae

36. Erman's birch (Betula ermanii)

37. Middendorff birch (Betula middendorffii)

38. Japanese white birch (Betula platyphylla)

39. Alder shrub forest (Duschekia fruticosa) 
Family Caprifoliaceae

40. Blue-berried honeysuckle (Lonicera edulis)

41. Lonicera chrysantha

Family Campanulaceae

42. Ladybell (Adenophora sp.)

Family Poaceae

43. Small reed (Calamagrostis sp.)

Family Ericaceae

44. Marsh Labrador tea (Ledum palustre)

45. Dahurian rhododendron (Rhododendron dauricum)

Family Vacciniaceae

46. Red bilberry (Vaccinium vitisidaea)

47. Cranberry (Oxycoccus microcarpus)

Family Pyrolaceae

48. Bog wintergreen (Pyrola asarifolia)

Family Salicaceae

49. Aspen (Populus tremula)

50. Willow (Salix sp.)

51. Chosenia arbutifolia

Family Cornaceae

52. Siberian dogwood (Cornus alba)

Family Onagraceae

53. Fireweed (Chamerion angustifolium)

Family Grossulariaceae

54. Sweet currant (Ribes fragrans)

55. Ribes procumbens Pall.

56. Dikusha currant (Ribes dikusha)

Family Pinaceae

57. Siberian spruce (Picea obovata)

58. Ayan spruce (P. ajanensis)

59. Mountain pine (Pinus pumila)

60. Dahurian larch (Larix gmelinii)

Family Woodsiaceae

61. Pseudocystopteris spinulosa

Family Cystopteridaceae

62. Brittle bladder fern (Cystopteris fragilis)

\section{Mammals}

Family Soricidae

63. Laxmann's shrew (Sorex caecutiens)

Family Cricetidae

64. Grey red-backed vole (Clethrionomys rufocanus)

Analysis of the rumen contents showed that shrub lichens make the biggest part in the nutrition structure of musk deer in almost all types of habitat. Detailed tracking also showed high specific weight of this forage. Its occurrence frequency is also high (Tabs 2 and 3 ).

Lichens eaten by musk deer were from 11 genera of three families. The most important species for these animals were bushy lichens (Evernia mesomorpha). According to the rumen content analysis, its specific weight is $24.92 \%$ (limits $1.00-85.5 \%$ ), according to tracking data, it is $23.18 \%$ (limits $1.37-76.60 \%$ ).

The most frequently consumed terrestrial lichens are Cladonia coccifera, C. rangiferina, and C. stellaris. The share of these three kinds made $22.81 \%$ (limits $5.10-82.10 \%$ ) among other kinds of forage in rumen samples, according to tracking data they made $11.11 \%$ (limits $1.37-43.84 \%$ ). Specific weight and frequency of occurrence in the lichen rumens (Usnea longissima) was insufficient - 5.23\% (limits $2.00-33.70 \%$ ). This species has been also found once during the tracking $4.45 \%$ (limits $1.37-8.22$ ). It is related to the local distribution of this kind of lichen on the Tukuringra Mountain Range (some valley areas, notches, northern exposure slopes), and also to the small amount of phytomass available.

Undoubtedly, musk deer were attracted by recently fallen trees covered with the Usnea lichen, but tracking showed that the animals rarely tried to look for this species intentionally either on the snow cover or on the tree branches.

Lichen share and species in the nutrition structure depended on the type of habitat (Tab. 4). The highest specific weight of lichen forage in the musk deer nutrition structure is found in open larch forests. In these areas their choice of lichen species depended on how thick and dense the snow cover was because if the snow was deep and the ice over it was dense, the musk deer had no access to the terrestrial species. In ripe larch forests with some birch trees or some spruces, the animals often eat arboreal and terrestrial species of lichens from the Parmeliaceae and Cladoniaceae families. Musk deer did not eat any lichens in burnt woods and black birch forest. In general, the average specific weight of the lichen forage in musk deer ration on the Tukuringra Mountain Range is comparable to the results of nutrition studies on other mountain ranges (Prikhod'ko, 2003), but the species composition of lichens is specific.

Shrubs and subshrubs are represented by 10 families, including 19 species, among which the most important ones are the representatives of the Ericaceae and Vacciniaceae families. Specific weight of these kinds of forage is also rather high. According to multiple day tracking data, Dahurian rhododendron contributes the largest share to the nutrition structure $(72.97 \%$, limits 43.65-94.04\%) in both burnt larch forests and black birch forests. As rhododendron is easily accessible, it is consumed by musk deer during winter periods with both big and small amounts of snow. Musk deer preferred red bilberry leaves and stems in sub-barrens spruce forests and in ripe larch forests with some spruces on the second layer, if the snow cover was not so thick. Specific weight of these areas was $20.23 \%$ (limits 7.6-27.3\%).

Bryophytes are represented by two species of two classes: sphagnum and frondiferous. Tracking results showed that the musk deer preferred Sphagnum mosses. Musk deer had this kind frequently in sub-barrens spruce forests and ripe larch forests with some spruces, where their share reached $11.67 \%$ (limits 4.26-24.32). In other kinds of habitat the bryophyte was rare in both food debris and rumen.

Among arboreal kinds of forage there are five families, including 11 species, among which four belong to 
Table 4. Rate of lichens among other types of forage in different types of musk deer habitats in the Tukuringra Mountain Range, according to the tracking data.

\begin{tabular}{|l|c|c|c|}
\hline \multirow{2}{*}{ Type of habitat } & Family Parmeliaceae & Family Cladoniaceae & Family Stereocaulaceae \\
\cline { 2 - 4 } & \multicolumn{3}{|c|}{ Specific weight, \% } \\
\hline Open larch forest & 27.40 & 48.66 & 1.37 \\
\hline Ripe larch forest with some birch trees & 30.79 & 19.35 & 0.00 \\
\hline Ripe larch forest with some spruces & 47.99 & 0.00 & 0.00 \\
\hline Black birch tree forest with oaks & 2.02 & 0.00 & 0.00 \\
\hline Burnt wood & 10.40 & 0.00 & 1.37 \\
\hline Sub-barrens spruce forest & 37.96 & 0.00 & 0.00 \\
\hline
\end{tabular}

coniferous and seven to larch trees. Animals ate pieces of rotten wood, bark, buds, needles, branches, and dry leaves that they found on parts of branches and soil surface. Share of this kind of forage is small (Tabs 2, 3). However, frequency of occurrence of some pieces (e.g. Dahurian larch needles) is rather sufficient, according to rumen analysis data. Musk deer consumed pieces of arboreal plants, while consuming other kinds of forage (lichens, fungi, subshrubs).

Herbaceous plants eaten by musk deer are represented by eight families, including 11 species. Specific weight of this kind of forage is not high. Frequency of occurrence of some plant species like Carex is rather high. The animals often found herbaceous forage on southern exposure slopes with rocky parts and in the valleys. The greatest variety of this kind of forage was found among food debris in black birch forest with oaks.

Fungi were represented by four species of four different families. The results of this study showed that the highest specific weight of all fungi had birch polypore. Trackings and observations showed that musk deer preferred this species frequently in burnt woods of 5-15 years old. After the fire some Japanese white birch trees died and formed large obstructions. These areas were favorable for this kind of fungus. Carefully going through these birch obstructions, the musk deer were finding arboreal fungi, spending two-three minutes near each carposome.

Pileate fungi of Russila sp. were found in ripe larch forest with some spruces on the second layer and in the undergrowth. In some cases musk deer tried to search for these fungi intentionally. Sometimes musk deer would find dry pileate fungi that were 10-15 m away and would make a sharp turn from the basic travel trajectory to the food item. Such cases were observed three times. In total 8 food debris of pileate fungi were found during trackings.

There was a grey red-backed vole found during one of the snow diggings. It was unfinished by musk deer. This case took place in the Kamenistaya River valley (right tributary of the Bolshaya Tynda River) in dense larch forest with spruces. Other remains of small mammals were also found in the musk deer rumens. In four rumens $(25 \%$ of all samples) there were parts of bones, skulls, balls of fur, upper jaw incisors, and a tail found. All these fragments belonged to two species: Laxmann's shrew and grey red-backed vole. Earlier there were cases of other species of even-toed ungulates eating small mammals (Mosolov \& Fil, 2010). Until now there has been only one case of a musk deer eating small mammals described in literature. Thus, one vole was found on the territory of the Sakha Republic in the Verkhoyansk Mountains, according to the rumen analysis data $(n=6)$ (Krivoshapkin, 2008).

\section{Conclusion}

Nutrition of musk deer varies during the snow period in the Tukuringra Mountain Range, that is related to the adaptation of animals to different habitats. Musk deer diet also depended on the depth of snow cover. The main types of forage were shrub lichens and shrubs. The musk deer prefers Evernia mesomorpha among all kinds of lichens. In the unfavorable conditions of food deficit (burnt woods, black birch forests with oaks), the importance of shrub and herbaceous forage increased, as well as that of the arboreal fungi. I have encountered the cases of musk deer consuming of small mammals. It may be related to the specific metabolism during the snow season and to the peculiarities of forage finding behavior during this period.

ACKNOWLEDGEMENTS. T.N. Veklich, O.P. Vin'kovskaya, G.F. Darman, N.A. Kochunova, S.A. Podol'skiy, V.V. Shchekina, S.S. Kalughniy, and K.P. Pavlova were involved into identification of species received in tracking and in rumen content analysis, which is deeply appreciated.

\section{References}

Abaturov B.D. 2005. [Forage resources, supply with food, and viability of herbivorous mammals] // Zoologicheskii Zhurnal. Vol.84. No.10. P.1251-1271 [in Russian, with English summary].

Argunov A.V. 2009. [Ecology of Siberian Roe Deer (Capreolus pygargus Pallas, 1771) in the Central Yakutia]. Dissertatsiya Kandidata Biologicheskikh Nauk [PhD Dissertation in Ecology]. Blagoveshchensk: Dalnevostoch- 
nyi Gosudarstvennyi Agrarnyi Universitet. 155 p. [in Russian].

Bannikov A.G., Ustinov S.K. \& Lobanov P.N. 1978. [Musk Deer of the USSR] // Sbornik Nauchnikh Trudov Moskovskoi Veterinarnoi Academii. Vol.97. P.6-36 [in Russian].

Domanov T.A. 2012a. [Musk deer areas of distribution and population (Moschus m. moschiferus Linnaeus) on the Tukuringra Mountain Range] // Amurskii Zoologicheskii Zhurnal. Vol.4. No.2. P.291-300 [in Russian, with English summary].

Domanov T.A. 2012b. [Winter nutrition of musk deer in Zeya Nature Reserve] // Materialy IV Mezhdunarodnoi konferentsii "Sovremennye problemy regional'nogo razvitiya". Birobidzhan. P.136-137 [in Russian].

Egorov O.V. 1965. [Wild Ungulates of the Sakha Republic]. Moskva: Nauka. 259 p. [in Russian].

Khumes F. (ed.). 2004. [No License to Kill: Musk Deer Population and Hunting, Trade of Musk Deer Gland in Russia and Mongolia]. Moskva: KMK Scientific Press \& TRAFFIC Europe. 99 p. [in Russian].

Gubanov I.A. 1981. [Flora and Vegetation of the Tukuringra Mountain Range (Amur Region)]. Moskva: Izdatel'stvo Moskovskogo Gosudarstvennogo Universiteta. 268 p. [in Russian].

Krivoshapkin A.A. 2008. [Musk deer (Moschus moschiferus Linnaeus, 1758) of the Yakutia Republic] // Vestnik Yakutskogo Gosudarstvennogo Universiteta. Vol.5. P.59 [in Russian].

Liu Z. \& Sheng H. 2000. A review of the ecology and conservation of musk deer (Moschus) in China // Chinese Journal of Zoology. Vol.3. P.54-57.

Maslov M.V. 2011. [Sika deer (Cervus nippon (Temm., 1838)) nutrition during non-vegetation period in the Ussuri Nature Reserve] // Amurskii Zoologicheskii Zhurnal. Vol.3. No.3. P.291-300 [in Russian, with English summary].
Mirutenko V.S., Lomanova N.V., Bersenev A.E., Morgunov N.A., Volodina O.A., Kuzyakin V.A. \& Chelintsev N.G. 2009. [Guidelines for Organizing, Holding, and Processing Data of Winter Route Records of Game Animals in Russia]. Moskva: Centrokhotcontrol. 69 p. [in Russian].

Mosolov V.I., Fil V.I. 2010. [Wild Reindeer of the Kamchatka Peninsula]. Petropavlovsk-Kamchatskii: Kamchatpress.158 p. [in Russian].

Novikov G.A. 2009. [Theoretical framework and methods of studying nutrition and food chains of mammals and birds] // Russkii Ornitologicheskii Zhurnal. Vol.154. P.673687 [in Russian, with English summary].

Prikhod'ko V.I. 1992. [Nutrition and eating behavior of musk deer] // Povedenie i Communicatsiya Mlekopitayushchikh. Moskva: Nauka. P.42-76 [in Russian].

Prikhod'ko V.I. 2003. [Musk Deer. Origin, Taxonomy, Ecology, Behavior, and Communication] Moskva: GEOS. 443 p. [in Russian]

Salmin Yu.A. 1972. [Life of Ussurian musk deer in the Central Sikhote-Alin Mts.] // Byulleten Moskovskogo Obshchestva Ispytatelei Prirody. Otdel Biologicheskii. Vol.77. No.4. P.30-42 [in Russian].

Shaposhnikov F.D. 1965. [Ecology of musk deer in the Northeastern Altai region] // Zoologicheskii Zhurnal. Vol.35. No.7. P.1084-1093 [in Russian, with English summary].

Ustinov S.K. 1969. [Winter nutrition of musk deer (Moschus moschiferus L.) in the Eastern Sayan Mountains] // Zoologicheskii Zhurnal. Vol.58. No.10. P.1558-1563 [in Russian].

Zaitsev V.A. 2006. [Musk Deer: Ecology, Population Dynamics, Conservation Prospects]. Moskva: Tsentr Okhrany Dikoi Prirody. 120 p. [in Russian].

Zheng S.W. \& Pi N.L. 1979. A study of the management of young wild musk deer // Acta Zoologica Sinica. No.25. P.176-186. 